\title{
E-Fulfillment and Multi-Channel Distribution - A Review
}

Niels Agatz, Moritz Fleischmann and Jo van Nunen

\begin{tabular}{|l|l|}
\hline ERIM REPORT SERIES RESEARCH IN MANAGEMENT \\
\hline ERIM Report Series reference number & ERS-2006-042-LIS \\
\hline Publication & August 2006 \\
\hline Number of pages & 34 \\
\hline Persistent paper URL & \\
\hline Email address corresponding author & nagatz@rsm.nl \\
\hline Address & Erasmus Research Institute of Management (ERIM) \\
& RSM Erasmus University / Erasmus School of Economics \\
& Erasmus Universiteit Rotterdam \\
& P.O.Box 1738 \\
& 3000 DR Rotterdam, The Netherlands \\
& Phone: + 31 10 408 1182 \\
& Fax: $\quad+31104089640$ \\
& Email: info@erim.eur.nl \\
& Internet: $\quad$ www.erim.eur.nl \\
\hline
\end{tabular}

Bibliographic data and classifications of all the ERIM reports are also available on the ERIM website: www.erim.eur.nl 


\section{ERASMUS RESEARCH INSTITUTE OF MANAGEMENT}

\section{REPORT SERIES \\ RESEARCH IN MANAGEMENT}

\begin{tabular}{|l|l|}
\hline ABSTRACT AND KEYWORDS \\
\hline Abstract & $\begin{array}{l}\text { This review addresses the specific supply chain management issues of Internet fulfillment in a } \\
\text { multi-channel environment. It provides a systematic overview of managerial planning tasks and } \\
\text { reviews corresponding quantitative models. In this way, we aim to enhance the understanding of } \\
\text { multi-channel e-fulfillment and to identify gaps between relevant managerial issues and } \\
\text { academic literature, thereby indicating directions for future research. } \\
\text { One of the recurrent patterns in today's e-commerce operations is the combination of 'bricks- } \\
\text { and-clicks', the integration of e-fulfillment into a portfolio of multiple alternative distribution } \\
\text { channels. From a supply chain management perspective, multi-channel distribution provides } \\
\text { opportunities for serving different customer segments, creating synergies, and exploiting } \\
\text { economies of scale. However, in order to successfully exploit these opportunities companies } \\
\text { need to master novel challenges. In particular, the design of a multi-channel distribution system } \\
\text { requires a constant trade-off between process integration and separation across multiple } \\
\text { channels. In addition, sales and operations decisions are ever more tightly intertwined as } \\
\text { delivery and after-sales services are becoming key components of the product offering. }\end{array}$ \\
\hline Free Keywords & Distribution, E-fulfillment, Online Retailing, Literature Review \\
\hline Availability & $\begin{array}{l}\text { The ERIM Report Series is distributed through the following platforms: } \\
\text { Academic Repository at Erasmus University (DEAR), DEAR ERIM Series Portal } \\
\text { Social Science Research Network (SSRN), SSRN ERIM Series Webpage } \\
\text { Research Papers in Economics (REPEC), REPEC ERIM Series Webpage }\end{array}$ \\
\hline Classifications & $\begin{array}{l}\text { The electronic versions of the papers in the ERIM report Series contain bibliographic metadata } \\
\text { by the following classification systems: } \\
\text { Library of Congress Classification, (LCC) LCC Webpage } \\
\text { Journal of Economic Literature, (JEL), JEL Webpage } \\
\text { ACM Computing Classification System CCS Webpage } \\
\text { Inspec Classification scheme (ICS), ICS Webpage }\end{array}$ \\
\hline
\end{tabular}




\title{
E-Fulfillment and Multi-Channel Distribution - A Review
}

\author{
Niels Agatz, Moritz Fleischmann, Jo van Nunen \\ RSM Erasmus University, PO Box 1738, 3000 DR Rotterdam, The Netherlands

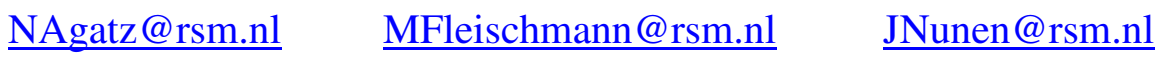

July 31, 2006

\begin{abstract}
This review addresses the specific supply chain management issues of Internet fulfillment in a multi-channel environment. It provides a systematic overview of managerial planning tasks and reviews corresponding quantitative models. In this way, we aim to enhance the understanding of multi-channel e-fulfillment and to identify gaps between relevant managerial issues and academic literature, thereby indicating directions for future research.

One of the recurrent patterns in today's e-commerce operations is the combination of 'bricks-and-clicks', the integration of e-fulfillment into a portfolio of multiple alternative distribution channels. From a supply chain management perspective, multi-channel distribution provides opportunities for serving different customer segments, creating synergies, and exploiting economies of scale. However, in order to successfully exploit these opportunities companies need to master novel challenges. In particular, the design of a multi-channel distribution system requires a constant trade-off between process integration and separation across multiple channels. In addition, sales and operations decisions are ever more tightly intertwined as delivery and after-sales services are becoming key components of the product offering.
\end{abstract}

Keywords: Distribution; E-fulfillment; Online retailing; Literature review

\section{Introduction}

Despite the end of the initial hype, Internet sales have seen tremendous growth rates over the past years (Forrester, 2005). While the retail market share of Internet sales is still small its quarterly growth rate of $8.6 \%$ in 2004 largely outweighs the 
corresponding 1.3\% growth of total retail sales (Dinlersoz and Hernandez-Murillo, 2005). After the initial over-enthusiasm, more sustainable models of e-commerce have started to emerge. One of the recurrent patterns is the combination of 'bricks-and-clicks', the integration of online sales into a portfolio of multiple alternative distribution channels. In 2003, multi-channel retailers accounted for $75 \%$ of the online sales in the United States (Forrester 2005). This development is fed from two sides. On the one side, many traditional retailers have added an online channel to their portfolio. On the other side, 'pure-play' Internet retailers are opening physical stores or are collaborating with traditional retailers, as in the case of Amazon.com and Borders Inc. in the U.S.A (www.amazon.com).

Hence, understanding the interplay between multiple channels is essential for understanding Internet fulfillment. While online sales and multi channeling provide rich opportunities, the design of the underlying distribution processes also confronts companies with novel complexities. To the best of our knowledge, no review article yet has addressed the specific supply chain management issues of Internet fulfillment in a multi-channel environment. This paper attempts to fill this gap by providing a systematic overview of the relevant issues and by linking them to available operational research models. Our objective is to twofold, namely to enhance the understanding of multichannel e-fulfillment by documenting the current state of affairs, and to inspire fruitful future research by identifying gaps between relevant managerial issues and available academic literature.

Before reviewing specific planning issues, a few additional comments on multichanneling appear worthwhile for setting the stage. Opportunities and challenges of a multi-channel strategy concern both marketing and operations management. Furthermore, decisions in both fields are ever more tightly intertwined.

From a marketing perspective, different channels differ in their abilities to perform various service outputs. The Internet channel is particularly powerful in providing information to the customer, thereby reducing the buyer's search costs. Offering multiple complementary channels provides a greater and deeper mix of customer service, thereby enhancing the seller's overall value proposition (Wallace et al., 2004). Channel preferences vary between customers. But even individual customers are 
increasingly becoming multi-channel shoppers, preferring different channels at different moments and at different stages of the shopping process (Nunes and Cespedes, 2003). On the downside, major marketing-related concerns in multi-channeling include cannibalization and channel conflicts (Webb, 2002). An additional distribution channel may partly cannibalize the sales of existing channels, rather than growing total sales. Conflicts may arise between different divisions managing a company's different channels, but even more so between different supply chain members, for example a manufacturer competing with its own resellers through a customer-direct Internet channel (Tsay and Agrawal, 2004). Consequently, managing the overall portfolio, rather than individual channels is key in multi-channeling.

From an operations management perspective, multi-channeling may yield synergies that help reduce e-fulfillment costs. E-fulfillment, delivering physical goods to the customer, is commonly cited as one of the most expensive and critical operations of Internet sellers (de Koster, 2002a, Lummus and Vokurka., 2002). Economies of scale from the integration of multiple channels need to be weighed against specific requirements of each individual channel. In particular, the economics of customer-direct Internet channels tend to differ from those of other channels due to small, single-order transaction sizes (Currah, 2002). Thus, companies need to make trade-offs when deciding which processes to integrate across channels and which processes to separate (Gulati and Garino, 2000).

The aforementioned marketing and operations management aspects are increasingly interrelated. Many markets have seen a shift from customers buying standalone physical products to customers seeking 'total solutions', i.e. a bundle of a physical product and related services. Services include, e.g., maintenance, consumable supplies, and end-of-life recovery. In an online channel, delivery is a key service element. Furthermore, just as mass customization has made the consumer a 'co-maker' of the physical product, companies are now tailoring their service processes to individual customers' needs. This means that customers are gaining significant impact on company processes, and it underlines the importance of coordinating marketing promises and operations capabilities. 
In the remainder of this paper we highlight the different planning tasks that arise in this setting. We proceed as follows. Section 2 delineates the exact scope of the paper and provides a framework that structures our discussion. Sections 3 and 4 form the core of this paper. They discuss supply- and delivery-related e-fulfillment issues, respectively. Each section first discusses managerial planning issues observed in practice and then reviews corresponding operational research models. Section 5 summarizes our conclusions.

\section{Scope \& Framework}

In this section we delineate the scope of our analysis and position it within the existing literature. Furthermore, we outline a framework that serves to structure our discussion throughout the remainder of the paper.

Several excellent review papers are available that address the impact of the Internet on supply chain management, including Keskinocak and Tayur (2001), Johnson and Wang (2002), Swaminathan and Tayur (2003), and Gimenez and Lourenco (2004). In addition, the handbook edited by Simchi-Levi and Wu (2004) provides a detailed overview of related research areas. What distinguishes our contribution is (i) the specific focus on fulfillment operations, (ii) the systematic comparison of managerial issues and quantitative tools, and (iii) the particular attention to multi-channeling.

The scope of this paper is primarily inspired by the perspective of a multi-channel retailer. Its focus is on physical distribution processes in $\mathrm{B} 2 \mathrm{C}$ e-commerce, i.e. on the processes that serve to convey a tangible product to the final consumer. These processes are commonly recognized as a key challenge in online distribution channels, primarily due to the difficulty of efficiently handling small transaction sizes of individual customer orders. We distinguish this setting from B2B e-commerce where the Internet primarily changes the information processes. The issues in our setting also differ from those in a manufacturer's Internet channel where channel conflicts due to disintermediation are a prime concern. This is an important field of its own right that has been extensively addressed in the literature (see e.g. Tsay and Agrawal, 2004). Furthermore, we focus explicitly on the distribution of physical products and therefore do not consider online channels of pure service businesses, such as banking, even though multi-channeling is an 
important marketing strategy in many service sectors (Coelho, 2004). Environmental and ecological consequences of Internet shopping are also beyond the scope of our paper (see Sarkis, 2004).

In the subsequent sections we address various planning issues arising in multichannel e-fulfillment. To structure the discussion we map the planning tasks on two dimensions, namely, the supply chain stage and the planning horizon (comp. Fleischmann et al., 2002).

\section{Insert Figure 1 about here}

Along the first dimension we distinguish the four supply chain stages depicted in Figure 1:

- Sales denotes all processes that directly interface with customer demand, such as pricing, order promising, and forecasting;

- Delivery encompasses the activities that physically move the product to the customer. In the case of home delivery, this is known as 'the last mile';

- Warehousing is concerned with the storage and handling function. Depending on the supply chain's decoupling point, the warehousing stage may be omitted or shifted to an upstream supply chain party;

- Purchasing is our term for all supply processes, notably ordering of final products.

Note that, in line with the previously explained retail perspective, we do not include a manufacturing stage.

On a second dimension, supply chain planning tasks are commonly structured according to the planning horizon, i.e. from long-term strategic to short-term operational. We follow this approach within each of the above supply chain stages.

For each planning task we first discuss what, if anything, distinguishes e-fulfillment from traditional supply chains. Secondly, we consider the potential interaction with other channels in a multi-channel context (see Figure 1 for an illustration). This concerns, in particular, trade-offs between integration and separation of processes across multiple channels. 
We emphasize that the above structuring only serves as a means for organizing our discussion. We do not mean to imply that the different planning tasks are independent or that the different supply chain stages should be managed in isolation. On the contrary, we recognize online information exchange as an important enabler of supply chain integration. The marketing-operations interface has been receiving much attention in the recent supply chain management literature (Marketing Science 50, 2004, Journal of Operations Management 20, 2002). This interface is particularly relevant in e-fulfillment since the delivery service is an essential component of the product offering. In other words, the customer buys a bundle of a physical product and a delivery service (and possibly other after-sales services). Consequently, companies need to coordinate their sales promises and their delivery capabilities. Because of this close interaction, we discuss sales and delivery planning tasks jointly in Section 3. Similarly, Section 4 encompasses warehousing and purchasing issues.

\section{Sales and Delivery Planning}

\subsection{Issues}

Traditional sales-related supply chain planning tasks include long-term product program planning, medium-term pricing and forecasting, and short-term order promising (see e.g. Fleischmann and Meyr, 2003). Particular features of these tasks in an e-fulfillment environment notably arise from the fact that the delivery service makes part of the product offering. Embedding in a multi-channel structure gives rise to additional tradeoffs. In what follows, we discuss the impact of these factors by planning task.

\section{Delivery Service Design}

As any company, Internet sellers need to design their product offering. In their case, this includes the choice of the offered delivery service, which is an important determinant of customer satisfaction (Boyer and Hult, 2005). The quality of the fulfillment service is addressed in a growing body of literature on Physical Distribution Services (Rabinovich and Bailey, 2004).

From a customer service perspective, concepts for bridging the 'last mile' to the customer can be divided into customer pick-up versus (home) delivery (Daduna and Lenz, 2005). The latter can be further subdivided into attended and unattended delivery 
(Kamarainen and Punakivi, 2002). While unattended delivery increases delivery flexibility, this concept is only applicable for products that can be safely deposited, e.g., in the customer's mailbox. The well-known example of U.S. online grocer Streamline illustrates the difficulty of extending unattended delivery to more sensitive product categories. Streamline went bankrupt after being unable to earn back its investments of providing customers with refrigerated reception boxes.

For attended home delivery, a company and its customer need to agree on a delivery time window. The length of this window and its timing during the day are important aspects of the customer's perceived service. The same goes for the delivery lead time, i.e. order placement and delivery. At the same time, all of these factors have an immediate impact on the seller's delivery costs. Striking the right balance between cost and service is challenging, in particular in highly competitive environments, such as the grocery market (see Boyer et al., 2003).

Another e-fulfillment service element concerns the handling of customer returns. Internet sales are facing particularly high return rates since customers cannot try and feel the product beforehand. For example, online apparel retailers are experiencing return rates amounting to up to $45 \%$ of their orders (Tarn et al., 2003; de Koster, 2002a). Costs of return handling, which include bridging the expensive 'last mile' for a second time, can easily eradicate the economic viability of an online channel. Therefore, designing efficient return processes is of prime importance (Min et al. 2006). At the same time, one observes again a trade-off between customer service, i.e. the return policy, and operational costs (Yalabik et al., 2005). One way, in which companies are trying to shift this balance is by offering support services, such as installation support for electronic products, aiming to reduce product returns.

Traditional sales channels offer many potential synergies for the marketing of an Internet channel. In particular, a well-established brand name helps build trust with the customer, which is essential for online sales (Chen and Dhillon, 2003). The presence of a traditional distribution structure also yields additional options for the delivery service design in e-fulfillment. Physical store pick-up points are a fairly common alternative to customer home delivery. Online orders are picked and packed in a store where the customers can then pick them up (www.bestbuy.com, www.freerecordshop.nl), possibly 
via a dedicated pick-up lane (www.lowesfoods.com, ww.foodfactory.nl). In this approach it is the customer who bridges the crucial 'last mile'. Other advantages of a pick-up structure include low capital investments and possible carry-over effects on in-store sales (Boyer et al. 2005, Johnson and Whang, 2002).

The presence of a physical distribution structure can be particularly beneficial for return handling. Most multi-channel retailers offer online consumers the option to return products via offline stores. This approach not only helps reduce return handling costs but it is also greatly valued by the customers (Forrester, 2005).

\section{Pricing and Forecasting}

Pricing decisions play a key role in any business. Service components, notably delivery, add an extra dimension to this issue in e-fulfillment. Companies need to set prices both for the physical products and for the delivery service. Common policies often combine both price elements, e.g. in the form of free delivery of sufficiently large orders.

Two factors render pricing a particularly powerful lever in online sales, namely significant pricing flexibility and extensive data availability. Typically, online sellers can change prices much more easily than traditional stores. Consequently, they can use pricing for short-term demand management (Baker et al., 2001). Besides dynamic posted prices, common online pricing policies include various types of auctions (Kambil and van Heck, 2002). Interestingly, many firms are selling almost identical products online through auctions and fixed prices simultaneously (Etzion et al. 2006). What complicates e-fulfillment pricing decisions is the need to anticipate on the ensuing cost consequences in the delivery operation. In addition, overly complex pricing policies may leave customers confused and distrustful (Garbarino and Lee, 2003).

The second major factor that increases pricing power in e-fulfillment is data availability. What is a major challenge for operations, namely dealing with individual customer orders, is a treasure for marketers. Availability of transaction data of individually identified customers not only provides a rich basis for forecasting but, more importantly, allows targeted communication with the customer. This explains the particular relevance of customer relationship management (CRM) in online retailing.

Detailed data provides a basis for segment-specific pricing and promotion. In particular, firms can effectively cross-sell products and services that closely match a 
particular customer's preferences, as in the example of Amazon.com suggesting additional book titles, based on the customer's browsing behavior (Akcura and Srinivasan, 2005). Effective cross-selling requires a firm to select appropriate product bundles and to design a corresponding pricing strategy. In conclusion, we see a shift from reactive forecasting to a much more active demand management in e-fulfillment.

The presence of a traditional sales channel adds further dimensions to the pricing decision. In particular, retailers need to choose whether to offer the same prices - and price changes, such as promotions - across all channels or whether to price-differentiate. Some retailers choose identical prices for the physical products and use additional delivery fees as the main steering element of the online channel (see e.g. www.albert.nl).

In addition, traditional sales channels benefit from the rich data collected in the online channel. Forrester (2005) argues that advanced multi-channel tactics include CRM across multiple channels.

\section{Order Promising and Revenue Management}

Traditionally, short-term sales planning centers around order promising, roughly speaking the seller's response to an incoming customer request. Order promising plays an important role in manufacturing. Planning systems use available-to-promise (ATP) quantities indicating the number of products that can be committed to a given delivery date (Fleischmann and Meyr, 2003). In traditional retailing, order promising is more straightforward since products are typically sold from stock. It is again the service component that adds to the complexity of order promising in e-fulfillment. In order to satisfy a customer order not only the requested product has to be available but also sufficient delivery capacity. Based on these factors, the Internet retailer has to commit to a certain lead-time or estimate-to-ship date. Flexibility in the quoted lead-times can help increase e-fulfillment efficiency ( $\mathrm{Xu}$ et al., 2006). In addition, the retailer may have some flexibility regarding where to retrieve the product - as opposed to physical stock in a traditional retail store (see Section 4 for a detailed discussion of inventory considerations in e-fulfillment.).

In general, customer orders differ with respect to their contribution margins and their delivery costs. This gives rise to revenue-management issues in e-fulfillment, similar to those well known in the airline and hospitality industry (McGill and Van Ryzin, 
1999). E-tailers have an incentive to use their delivery capacity for the most profitable orders. In the case of high utilization it may not be optimal to simply accept all orders first-come-first-serve until capacity is exhausted. The benefits of a more selective approach increase with increasing order heterogeneity and with decreasing capacity. What distinguishes this situation from classical revenue management is the cost impact. In contrast with the prototypical 'airline' setting, marginal costs of an order are nonnegligible in e-fulfillment and, what is more, delivery costs for different orders may be interdependent.

E-tailers have different revenue management levers at their disposal, including dynamic pricing and a dynamic adjustment of the offered delivery options (e.g. time slots). This links order promising to the short-term pricing decisions discussed above. In all of these cases, revenue management benefits from the real-time availability of rich customer data. Again, maintaining a certain level of transparency may be important for customer satisfaction.

In a multi-channel setting, order promising may cross the boundaries of individual channels. For example, in-store inventories may be available to online buyers. In this case, customer segmentation based on channel type, and a corresponding prioritization in order promising, may be beneficial since opportunity costs of missed sales tend to differ by channel.

\section{Transportation Planning}

On the delivery side, short-term planning concerns the actual transportation of the goods to the customer. The scope of this operation closely depends on the chosen delivery concept, as indicated earlier. In the case of in-store pick-up, 'transportation' may be limited to moving the goods to a check-out counter. Combining shipments with regular store replenishments may yield economies of scale.

Home-delivery implies a more extensive operation. Cost-efficient processing of small transaction sizes is a major challenge. Especially in the case of low-value items, such as groceries, transportation costs are a key determinant of the business viability. Hub-and-spoke networks provide a common way to create economies of scale while expanding geographical coverage (see e.g. www.ocado.com). 
Dedicated home delivery, as opposed to e.g. delivery by mail, requires the planning of appropriate transportation routes. The degree of routing flexibility and thus transportation efficiency closely depends on the delivery service design, notably on the offered delivery time-windows.

In B2C Internet retailing new routing schedules have to be planned more frequently (usually daily or twice a day) than in a traditional B2B delivery environment because many B2C orders are impulse buys whereas B2B purchases are often repetitive (Buck Consultants, 2006). This leads Du and Chou (2005) to argue that B2C environments exhibit a greater need for quick-response dynamic vehicle dispatching systems than B2B environments.

\subsection{Models}

In this subsection, we relate the e-fulfillment sales and delivery issues discussed in the previous subsection to quantitative decision support models presented in the academic literature. We use the same structuring as above. Table 2 at the end of this paper lists the models by category.

\section{Delivery Service Design}

Regarding the choice of the e-fulfillment product offering, the modeling focus in the literature has been on the delivery service. Several authors have addressed the issue of choosing an appropriate delivery service level, in terms of time windows and lead times. Some of the proposed models directly optimize the service offering by considering both costs and revenues. Other models take a what-if approach, highlighting the cost impact of a given service offering.

Several papers related to the ECOMLOG project of the University of Helsinki present simulation-based analyses of different delivery strategies for e-groceries (Punakivi et al., 2001a,b, 2002; Yrjola, 2001). Yrjola (2001) develops cost estimates for several alternative fulfillment strategies. The results award particular potential to hybrid structures that gradually expand e-fulfillment capabilities of traditional stores. Punakivi et al. (2001a,b, 2002) compare transportation costs for attended and unattended delivery and assess the impact of the delivery window length. The results illustrate the efficiency gains of relaxed time constraints. Fully flexible, unattended delivery reduces costs by up to a 
third, relative to attended delivery within two-hour windows. Similarly, Lin and Mahmassani (2002) use simulation to evaluate the impact of different delivery policies on the operations of an e-grocer. They illustrate the trade-off between delivery cost and customer service by highlighting the potentially significant cost impact of tight delivery time windows. Robuste et al. (2003) model the effect of time windows on delivery efficiency by continuous approximation. They demonstrate that the impact of time windows increases with increasing delivery vehicle capacity. Hsu and Li (2005) seek optimal delivery shipment cycles that strike a balance between delivery costs and customer service in terms of delivery lead times. They present a non-linear profit maximization model with lead-time dependent demand. Costs include purchasing, transportation, and inventory. Numerical examples illustrate the benefit of adjusting shipment frequencies to temporal and regional demand variations, rather than imposing a static policy.

We are not aware of any optimization models that explicitly consider delivery service choices in a multi-channel setting, e.g. choosing between home delivery and store pick-up. The reason may be that the number of alternatives for these strategic choices is small, so that they can be addressed separately, rather than requiring a comprehensive overall model.

What may be more remarkable is the scarcity of optimization models for return policies in e-fulfillment. This is in sharp contrast with the extensive literature on end-oflife returns on the one hand (see e.g. Dekker et al., 2003) and with the many models of buy-back contracts for supply chain coordination on the other hand (see e.g. Tsay et al., 1998). In the spirit of the latter, Yalabik et al. (2005) propose a game theoretic model that is tailored towards a retail environment. Specifically, they model a retailer's buy-back price decision, which influences demand of two customer segments.

\section{Pricing and Forecasting}

The marketing literature reflects a long history of customer choice models (Erdem and Winer, 2002). Detailed data on Internet browsing and on e-commerce transactions opens significant opportunities for additional empirical research in this field. Van den Poel and Buckinx (2005) and Jenami et al. (2003) are examples of recent papers which concentrate on explaining and predicting customer behavior on the Web. 
The aforementioned models are primarily descriptive. In addition, a significant stream of prescriptive models is available for short term price optimization. Making part of the well-publicized field of Revenue Management (Talluri and van Ryzin, 2004), these models assess in particular the benefits of dynamic pricing policies over more stable prices (see for example Gallien, 2006). While not all of these models are focusing on efulfillment specifically many of them appear to be applicable, due to the particular pricing flexibility in online sales. The same goes for the large set of auction and bidding models (Kalagnanam and Parkes, 2004).

The above models essentially maximize revenues. Another line of research explicitly aims to integrate cost and revenue effects of dynamic pricing. In particular, many authors have proposed combined inventory-pricing models. For a more detailed review of this rapidly expanding stream of research we refer to Chan et al. (2004) and to Elmaghraby and Keskinocak (2003).

As discussed in the previous subsection, the impact of dynamic pricing on e-fulfillment delivery costs appears to be particularly relevant. We are aware of two models explicitly addressing this issue. Asdemir et al. (2002) propose a dynamic pricing model for the delivery windows of a grocery home delivery operation. Similar to standard revenue management models, demand is stochastic and includes several customer classes. The model uses dynamic prices per customer class to balance capacity utilization. The authors analyze the structure of the optimal pricing policy in a Markov decision problem and numerically investigate the profit increase relative to a constant pricing policy. Campbell and Savelsbergh (2006) also consider price incentives to influence a customer's choice of a delivery window in a home-delivery operation. They propose a deterministic optimization model for choosing the discounts that explicitly captures the routing costs of a given order. A simulation analysis documents that the suggested incentive schemes can significantly enhance profit.

Another stream of pricing-related research is concerned with optimal crossselling. Kamakura et al. (2003) use a combination of survey data and customer databases to identify opportunities for cross-selling. They propose a statistical model that aims to predict customers' likely buying behavior. This then serves as a basis for selecting the best prospects for cross-selling new products or services. Wong et al. (2005) propose a 
data-mining algorithm for finding a profit-maximizing set of items for cross-selling. They approximate the initial model by a quadratic program, which they solve heuristically. Netessine et al.(2005) consider the problem of dynamically cross-selling products or services in an e-commerce setting. Following a revenue-management approach, they develop a stochastic dynamic program for a finite horizon, multi-item inventory system. In each period, the company needs to decide which products to bundle and which price to charge for this bundle. The authors suggest several solution heuristics and test them numerically. The results suggest that dynamic cross-selling is most beneficial when inventory approximately equals expected demand. In a slightly different setting, Akcura and Srinivasan (2005) consider an online retailer's opportunities for cross-selling customer information to a third party. The paper proposes a game-theoretic model for the interaction between the retailer and the consumer. The results suggest that firms can achieve customer intimacy by committing against excessive cross-selling.

Pricing models for a multi-channel setting appear to be scarce as yet. For a review of general coordination issues between traditional and Internet channels see Cattani et al. (2004). We are aware of only one model that specifically addresses pricing decisions of a multi-channel retailer. Cattani et al. (2006) analyze optimal pricing policies in this setting for different degrees of autonomy of both channels. They assume that an individual customer's utility of buying a product decreases in the product price and in the channelspecific purchasing effort. Based on computational experiments, the authors conclude that optimizing web-channel prices without changing store prices often provides a reasonable heuristic for maximizing total profits.

\section{Order Promising and Revenue Management}

Revenue management has grown into a major field of research over the past decade. Model variants abound (see Talluri and van Ryzin, 2004). Broadly speaking, the underlying managerial task is to sell scarce resources to the most profitable customers. In a retail setting, these allocation decisions are often intertwined with inventory replenishment decisions. We discuss the corresponding models in Section 4 in the context of inventory management.

As explained in Section 3.1, the e-fulfillment delivery process yields additional criteria for differentiating between customers. Depending on the requested delivery time 
and location, some customers may be more expensive to serve than others. Thus, if capacity is scarce, delivery cost differences should be taken into account when deciding which orders to accept. We are aware of only one paper that explicitly addresses this issue. Campbell and Salvelsbergh (2005) propose a model for deciding whether to accept or reject an incoming home delivery request. Their analysis is based on insertion heuristics for a vehicle routing problem. They suggest several variants for incorporating expected future orders. A numerical study compares these variants and underlines their superiority over a simple first-come-first-serve order acceptance.

We see the development of revenue management approaches for home delivery operations among the most relevant current research issues in e-fulfillment and expect significant additional contributions in the future.

\section{Transportation planning}

Vehicle routing is a classical field of combinatorial optimization. Modeling and algorithmic contributions abound (see e.g. Toth and Vigo, 2001). Braysy and Gendreau (2005a,b) provide a recent survey of solution algorithms for vehicle routing problems with time windows (VRPTW).

Many of these models appear also to be applicable in e-fulfillment. The particular challenges of this environment, such as significant cost pressure, seem to affect parameter values primarily, rather than the underlying problem structure. VRP variants that seem particularly relevant in an e-fulfillment setting include the Dynamic Vehicle Routing Problem (DVRP), in which new orders arrive during operation (Fleischmann et al., 2004). But also the Period Vehicle Routing problem with Service Choice (PVRP-SC), in which delivery routes must be constructed for multiple periods and delivery frequency is a decision variable, looks relevant for home delivery operations (Francis et al. 2004, 2005).

Weigel and Cao (1999) report on a vehicle routing problem with time windows in e-fulfillment at Sears, Roebuck and Company. Sears operates the largest furniture and appliances home-delivery service in the U.S.A. The authors construct a series of algorithms tailored to handling the large problem size. Du et al. (2005) emphasize the dynamic nature of e-fulfillment and propose a combination of several existing algorithms for quick-response delivery in an online B2C environment. 
Xu et al. (2006) link transportation planning to inventory deployment. Specifically, they consider the re-allocation of accepted customer orders to different warehouses while maintaining the original lead time commitment. Re-allocation may reduce transportation costs by taking into account more recent additional orders. The magnitude of these benefits depends on the degree of lead-time flexibility. This problem highlights the hierarchical planning structure of order promising and execution. The authors formulate the re-evaluation problem as a multi-commodity flow model. They propose near-optimal heuristics and apply them to an illustrative case of a global Internet retailer.

\section{Supply Management}

\subsection{Issues}

In the previous section we addressed issues and models related to the delivery and sales function of e-fulfillment. In this section we consider the processes further upstream in our supply chain framework (see Figure 1). Supply and storage are the key functions at these stages. Corresponding planning issues range from long-term design issues to short-term execution. Particularities of e-fulfillment mainly arise from small transaction sizes. Important trade-offs of multi-channeling regard the aggregation of inventories. In what follows, we discuss these issues systematically.

\section{Distribution Network Design}

Network design, including the choice of facility locations and corresponding transportation links, is a key strategic decision in any supply chain. In a retail environment, location choices mainly concern storage and transshipment facilities. The same is true in e-fulfillment. What is particular here is the fact that inventories are decoupled from customer display. This increases the e-tailer's flexibility in locating inventories (Randall et al., 2006). On the other hand, inventory locations are closely linked to the design of the delivery process discussed in the previous section. In conclusion, it is a trade-off between economies of scale and risk pooling on the one hand and delivery efficiency on the other hand that drives inventory locations and, in particular, the degree of inventory centralization. The impact of the delivery component 
is particularly important because of the relatively small transaction sizes, which often entail significant transportation costs.

The absence of physical inventory on display allows Internet retailers to avoid inventory ownership altogether by delivering customer orders directly from their suppliers' inventories. In this arrangement, known as drop-shipping, the retailer focuses on the sales function, and leaves the physical fulfillment processes to the supplier (Bailey and Rabinovich, 2005).

Drop shopping is a common practice for non-perishable make-to-stock items, such as books and CD's. It provides a means for risk pooling by integrating the inventories of multiple retailers or retail outlets, which enables them to offer a larger assortment. On the other hand, the retailer concedes some of his margins, control, and customer proximity to his supplier (Randall et al., 2002). For a viable co-operation, retailer and supplier need to strike a balance between service level agreements and delivery costs.

A multi-channel setup yields obvious potential synergies on the supply side. Arguably, the biggest advantage concerns greater purchasing power and the leverage of established supplier relationships. Other synergies may arise in the physical distribution network. In particular, multiple channels may share inventories, thereby reaping pooling benefits. However, economies of scale can be hampered by different transaction sizes in different channels, e.g. pallet-sized orders of a retail store versus individual items in e-fulfillment. In this context, it is worth noting that storage facilities of an e-fulfillment channel share characteristics both with traditional warehouses and with traditional stores. It depends on the specific e-fulfillment channel which correspondence prevails. This is reflected in three types of e-fulfillment structures commonly distinguished in the literature (de Koster, 2002a,b; Lummus et al., 2002):

- Integrated fulfillment - building e-fulfillment capability into existing distribution centers that also deliver conventional stores;

- Dedicated fulfillment - via a purpose-built "green-field" operation;

- Store fulfillment - picking online orders from regular retail shelves for separate, dedicated delivery; 
Murphy (2003) discusses some of the key e-grocery initiatives in North America, distinguishing between store-based versus warehouse-based fulfillment. He underlines that space constraints limit the e-fulfillment volume in the store-based model since professional order pickers and regular customers interfere with each other. Yrjola (2002) propose a hybrid approach in which the fulfillment structure differs by product.

\section{Warehouse Design}

Another set of strategic issues concerns the internal design of storage facilities.

Traditional issues in warehouse design include the selection of a proper storing method, the choice of appropriate handling equipment, and the warehouse layout (de Koster et al. 2006). Order picking costs account for the largest part of warehousing operating costs. This is even more true in $\mathrm{B} 2 \mathrm{C}$ e-fulfillment operations, which typically involve small pick quantities from a large number of items. Split-case or piece-picking are common picking methods in this kind of environments. These are relatively more labor-consuming than case or pallet picking.

In a $\mathrm{B} 2 \mathrm{C}$ environment, picking quality is highly important since the assembled order is delivered directly to the end-customer. Picking quality can be supported by advanced picking technologies, such as radio frequency terminals, wireless speech technology, and pick/put-to-light systems. However, viability of the corresponding investments requires high order volumes.

In Section 3 we discussed the particular relevance of product returns in e-fulfillment. This is also reflected in the warehouse design. A large fraction of the returned products is essentially as good as new and can therefore be resold. However, this requires a systematic process for feeding returns back into inventory, possibly after inspection or cleaning (de Brito and de Koster, 2003).

As discussed above, a multi-channel setting offers opportunities for integrating inventories of different channels at a single location, which can be a warehouse or a store. In general, however, this will require design adjustments to make these locations fit for efficient Internet order picking.

\section{Inventory and Capacity Management}

Medium and short term planning tasks on the supply side of e-fulfillment focus on inventory replenishment. Based on demand forecasts, appropriate stocking levels need to 
be determined for each storage location. In particular, this includes setting safety stocks to buffer against demand uncertainty.

At first sight, inventory management in an Internet channel differs by little from any other channel. What adds novel characteristics to this process is the interrelation with demand fulfillment. We have argued in Section 3 that online sales offer particularly rich opportunities for dynamic pricing and revenue management. Inventory management needs to anticipate on this type of short-term demand management for setting appropriate stocking levels.

This holds, in particular, in the case of joint inventories for multiple channels. As discussed earlier, different channels may imply different opportunity costs for lost sales and therefore require different service levels. These different requirements need to be aggregated into an overall inventory level and an accompanying fulfillment policy.

Also the aforementioned product returns impact inventory management in an Internet channel. If the return volume is significant it may be advisable to take outstanding returns into account when placing a replenishment order, especially in the case of long supplier lead times.

In addition to physical product inventory, e-tailers need to manage their fulfillment capacity. This reflects again the service component of the Internet channel's product offering. Capacity management, notably workforce planning, corresponds with the 'replenishment' of this service component. In particular, staffing levels need to be adjusted to seasonal demand fluctuations. This includes both delivery and order picking capacity. Since delivery requirements tend to be more variable and more interrelated across orders than picking requirements, capacity management of the delivery process appears more challenging.

\subsection{Models}

In what follows, we review models from the Operational Research literature that correspond with the previously identified supply-oriented planning issues in e-fulfillment. Table 2 summarizes these models.

\section{Distribution Network Design}


Discrete location-allocation models form the prevalent modeling approach to distribution network design. Countless modeling variants are available in the literature, ranging from simple single-stage, single-product models to complex non-linear probabilistic models. For a recent and extensive review and classification of facility location models see Klose and Drexl (2005).

In principle, many of the standard models also appear to be applicable to the network design of an online channel. This may explain why one does not find many network design models that focus on e-fulfillment specifically. A notable exception concerns drop-shipping models, focusing on inventory placement. Typically, these models combine strategic inventory allocation issues and operational inventory control. We discuss those models that focus primarily on the operational component in a separate subsection on inventory management below. Among the more strategic models, Netessine and Rudi (2006) examine drop-shipping arrangements from a supply chain coordination perspective. They propose a game-theoretic model of a two-echelon supply chain comprising a wholesaler and multiple retailers. A single-period analysis reflects the trade-offs related to inventory risk and its impact on the optimal channel choice.

Netessine and Rudi (2004) consider a multi-period variant of this model. They argue that drop-shipping entails a marketing-operations misalignment that results both in understocking and in deficient customer acquisition. Consequently, for both the retailer and the wholesaler drop shipping is only beneficial in the case of a relatively high wholesale price. The authors show how to coordinate this supply chain by means of contracts.

Several models in the literature consider the impact of product returns on logistics network design (see e.g. Fleischmann et al., 2003). Min et al. (2006) focus on e-fulfillment specifically. They propose a model for locating return centers that consolidate returned products before shipping them to a central repair facility. The model focuses on trade-offs between freight rate discounts and inventory reduction. The authors formulate a non-linear mixed-integer programming model and solve it using a genetic algorithm.

Despite the apparent trade-offs and the heterogeneous solutions observed in practice, we found few quantitative models addressing a multi-channel distribution network design. The available models focus mainly on inventory aggregation effects and 
rely on multi-echelon inventory theory. Specifically, they consider divergent two-echelon systems with a central warehouse at the top echelon and retail stores at the bottom echelon. Alptekinoglu and Tang (2005) develop a model of the distribution of a single product to multiple sales locations through multiple cross-docking depots. The authors determine ordering and allocation policies for each depot that minimize total expected distribution costs. They compare two fulfillment scenarios, namely fulfillment from the store or from the warehouse. The model highlights the risk pooling benefits of inventory aggregation. Chiang and Monahan (2005) study a two-echelon inventory model comprising two alternative distribution channels, namely traditional retail stores and an Internet-enabled direct channel that is served from a central warehouse. The system receives stochastic demand from two customer segments that differ in their channel preferences. The paper compares three different distribution strategies, namely storeonly, Internet-only, and a combined bricks-and-clicks approach. Numerical examples show the dual-channel strategy to outperform both of the single channels.

\section{Warehouse Design}

For a general review of models concerning the design and control of order-picking operations we refer to de Koster et al. (2006). Small transaction sizes render order picking more labor intensive for an Internet channel, thereby increasing the need for efficiency. A few authors have proposed specific models for warehouse operations in a B2C e-commerce setting.

Two papers consider split case sorting systems that sort items from opened (or 'split') cases into the corresponding customer orders. Johnson and Meller (2002) study the performance of such an automated split-case sorting system. They develop analytic performance models for different system configurations. Russel and Meller (2003) address the decision of whether or not to automate the split-case sorting process. They develop a descriptive model of the major trade-off between picking and packing efficiency. Batching increases the picking efficiency but decreases the packing efficiency. The model is used to evaluate alternative system designs. Xu (2005) studies a two-region warehouse in an e-tailing setting. One region is used for order picking, the other holds reserve stock. The author models this system as a stochastic multi-item two-stage, serial inventory system with space constraints. 
We are not aware of any quantitative models addressing the integration of product returns into warehousing processes in e-fulfillment. For a qualitative discussion we refer to de Brito and de Koster (2003).

\section{Inventory and Capacity Management}

As discussed in the previous subsection, particular inventory management issues in e-fulfillment arise from the interaction with short-term demand management. Some of these issues are addressed by inventory rationing models. Inventory rationing is a yield management strategy for a heterogeneous market that reserves some inventory for high margin customers. The corresponding models generally consider two customer segments with different contribution margins and different service time requirements. Kleijn and Dekker (1998) surveyed many of the early papers in this field. More recent contributions to the inventory rationing literature that specifically address online channels include Cattani and Souza (2002) who compare the benefits of inventory rationing over a simple first-come-first-serve policy in different scenarios. In particular, their numerical study considers different customer reactions to delay, namely lost sales and backlogging. Ayanso et al. (2006) consider a similar model. They assume that orders that cannot be satisfied from stock are drop-shipped from the supplier. The paper illustrates the impact of several problem parameters in a simulation study. In addition, it highlights the importance of determining the correct threshold level in inventory rationing. Ding et al. (2006) consider the use of dynamic price discounts to encourage backlogging of demand from those customer classes that are denied immediate service. The paper develops dynamic programming algorithms to determine both the optimal discount offer and the allocated quantity in each period.

As discussed earlier, a few authors have analyzed inventory control policies for e-fulfillment with drop-shipping. Bailey and Rabinovich (2005) propose a model that is inspired by the situation of an Internet book retailer who can serve demand either from his own inventory or by drop shipping. Assuming fixed plus linear cycle costs, the authors develop analytic expressions for the optimal order quantities of both fulfillment options and analyze their sensitivity to several input parameters. The results show in particular, that it can make sense to use both fulfillment options simultaneously. Khouja (2001) comes to a similar conclusion based on a news vendor type of analysis. He 
assumes that only a fraction of the customers is willing to accept drop shipping in the case of shortage of in-house inventory. The model identifies the optimal mix between both fulfillment options.

An extensive stream of literature addresses the integration of product return flows into inventory systems (see e.g. van der Laan et al., 2003). Most of these models are concerned with the remanufacturing of end-of-life returns. Recent models that consider returns from direct channel sales include Vlachos and Dekker (2003). They develop news vendor formulations for several problem variants and derive analytic expressions for the corresponding optimal order quantities. Mostard et al. $(2005,2006)$ extend this model by allowing more general demand-return relationships. They compare the optimal order quantities for different demand distributions and develop a distribution-free heuristic that appears to perform well in most realistic cases.

\section{Conclusions}

In this paper, we addressed key issues in B2C e-fulfillment from a multi-channel perspective. Moreover, we reviewed corresponding quantitative models in the Operations Research literature. In this section we summarize our main observations and draw conclusions for future research directions.

\section{Insert Table 1 about here}

Table 1 highlights the main planning issues in e-fulfillment and multi-channeling that we identified in Sections 3 and 4. Many standard supply chain management issues are also relevant for e-fulfillment. However, a few aspects appear to be specific. This includes the service component inherent to e-fulfillment. An online channel does not only provide a physical product but also related services, notably delivery. The delivery service may range from making the product available for pick-up to time-specific home delivery. The management of this service component of e-fulfillment gives rise to novel planning issues. On the one hand, companies need to choose an appropriate level of delivery service and a corresponding price. On the other hand, they need to manage the necessary resources, notably transportation capabilities, to provide this service. 
Another set of issues that appears to be characteristic of e-fulfillment concerns demand management. Typically, online sellers are more flexible than traditional retail channels with respect to pricing and order promising. While this flexibility generates a significant potential for increasing revenues through differentiation, it also implies the need for appropriate strategies to be successful. This holds in particular in combination with the aforementioned service elements. Demand management has an immediate impact on service requirements and thus on costs, which requires both factors to be coordinated in order to maximize profit.

A third area worth noting regards the multi-channel embedding of many of today's successful Internet channels. Multi-channel retailers often achieve important synergies in terms of increasing market power, both on the sales and on the purchasing side. With respect to the fulfillment processes, one typically observes a trade-off between economies of scale from the integration of multiple channels on the one hand and efficiency gains from a dedicated process design on the other hand. These trade-offs arise, for example, in the location and layout of facilities and in the aggregation of inventories. The latter case also raises issues in inventory deployment since different channels may require different service levels. Therefore, a simple first-come-first-serve policy may be inappropriate for inventories shared across multiple channels. CRM plays an important role in providing the basis for more differentiated deployment strategies.

\section{Insert Table 2 about here}

Many standard Operations Research models provide a good basis for addressing supply chain planning issues in e-fulfillment and multi-channel distribution. Yet, specific issues warrant modeling extensions and novel approaches. Table 2 lists the models that we reviewed in this paper, which address specific e-fulfillment issues.

A few observations are in order. First of all, the number of dedicated models to date is remarkably small. We see room for significant contributions in literally all areas of e-fulfillment.

This holds, in particular, for the integration of supply and demand management. Over the past decade, many researchers have contributed to building a solid basis for 
revenue management and dynamic pricing. More recently, these demand management elements have been integrated in inventory control models. Applications in e-fulfillment call for a similar integration of demand management and distribution management. To date, very few contributions have addressed this integration. Given the significant demand management flexibility in e-fulfillment, we see a huge potential for highly relevant research contributions. Asdemir et al. (2002), Campbell and Savelsbergh (2005), and $\mathrm{Xu}$ et al. (2006) provide valuable starting points in this direction.

Another remarkable observation concerns the very small number of models that explicitly address the multi-channel context of many of today's Internet retailers. This is in striking contrast with the huge number of papers dedicated to channel conflicts. Qualitative literature and managerial contributions highlight a number of important trade-offs in the design of multi-channel fulfillment processes. The management of these trade-offs would greatly benefit from a systematic quantitative analysis. In addition, such analyses would also provide a valuable building block for intra-organizational supply chain studies, by providing more realistic cost structures.

In conclusion, we see significant opportunities for managerially relevant and theoretically challenging contributions in the field of e-fulfillment and multi-channel distribution. Hopefully, this review can help stimulate this line of research.

\section{References}

Akcura MT, Srinivasan K. 2005. Research Note: Customer intimacy and cross-selling strategy. Management Science 51(6): 1007-1012

Alptekinoglu A, Tang CS. 2005. A model for analyzing multi-channel distribution systems. European Journal of Operational Research 163(3): 802-824

Asdemir K, Jacob VS, Krishnan R. 2002. Dynamic Pricing of Home Delivery. Working Paper, The University of Texas at Dallas, Richardson, TX

Axsäter S, Kleijn M, De Kok TG. 2004. Stock rationing in a continuous review twoechelon inventory model. Annals of Operations Research 126(1-4): 177-194 
Ayanso A, Diaby M, Nair SK. 2006. Inventory rationing via drop-shipping in Internet retailing: A sensitivity analysis. European Journal of Operational Research 171(1): $135-152$

Bailey JP, Rabinovich E. 2005. Internet book retailing and supply chain management: An analytical study of inventory location speculation and postponement. Transportation Research Part E: Logistics and Transportation Review 41(3): 159-177

Baker W, Marn M, Zawada C. 2001. Price smarter on the Net. Harvard Business Review 79(2): 122-127

Boyer KK, Hult GT, Frohlich M. 2003. An exploratory analysis of extended grocery supply chain operations and home delivery. Integrated Manufacturing Systems 14(8): $652-663$

Boyer KK, Frohlich M, Hult GT. 2005. Extending the Supply Chain: How Cutting-Edge Companies Bridge the Critical Last Mile into Customers' Homes. Amacon: New York

Boyer KK, Hult GTM. 2005. Extending the supply chain: Integrating operations and marketing in the online grocery industry. Journal of Operations Management 23(6): $642-661$

Braysy I, Gendreau M. 2005a. Vehicle routing problem with time windows, Part I: Route construction and local search algorithms. Transportation Science 39(1): 104-118

Braysy I, Gendreau M. 2005b. Vehicle routing problem with time windows, Part II: Metaheuristics. Transportation Science 39(1): 119-139

Buck Consultants International 2006. Final Report: Thematic Network on e-Fulfilment.

Campbell AM, Savelsbergh MWP. 2005. Decision support for consumer direct grocery initiatives. Transportation Science 39(3): 313-327

Campbell AM, Savelsbergh MWP. 2006. Incentive Schemes for Attended Home Delivery Services. Transportation Science 40(3): 327-341

Cattani KD, Souza GC. 2002. Inventory rationing and shipment flexibility alternatives for direct market firms. Production and Operations Management 11(4): 441-457

Cattani KD, Gilland WG, Swaminathan J. 2006. Adding a Second Channel? How the Degree of Autonomy Affects Prices and Profits. Working Paper, The Kelley Scholl of Business, Indiana University, Bloomington, IN 
Cattani KD, Gilland WG, Swaminathan JM. 2004. Coordinating Traditional and Internet Supply Chains. In: D Simchi-Levi et al. (Eds), Handbook of Quantitative Supply Chain Analysis: Modeling in the E-Business Era. Kluwer: Boston; 2004. p. 643-677

Chan LMA, Max Shen ZJ, Simchi-Levi D, Swann JL. 2004. Coordination of pricing and inventory decisions: A survey and classification. In: D Simchi-Levi et al. (Eds), Handbook of Quantitative Supply Chain Analysis: Modeling in the E-Business Era. Kluwer: Boston.; 2004. p. 335-392

Chen SC, Dhillon GS. 2003. Interpreting Dimensions of Consumer Trust in E-Commerce. Information Technology and Management 4(2-3): 303-318

Chiang W-YK, Monahan GE. 2005. Managing inventories in a two-echelon dual-channel supply chain. European Journal of Operational Research 162(2): 325-341

Coelho FE, C. 2004. Multiple channel systems in Services: Pros, Cons and Issues. The Service Industries Journal 24(5): 1-29

Currah A. 2002. Behind the web store: The organisational and spatial evolution of multichannel retailing in Toronto. Environment and Planning A 34(8): 1411-1441

Daduna JR, Lenz B. 2005. Online-Shopping and Changes in Mobility. In: B Fleischmann, A Klose (Eds), Distribution Logistics: Advanced Solutions to Practical Problems. Springer: Berlin; 2005. p. 65-84

de Brito MP, de Koster MBM. 2003. Product returns: Handling and warehousing issues. In R Dekker et al (Eds.), Reverse Logistics: Quantitative Models for Closed-Loop Supply Chains. Springer: Berlin; 2003. p.135-153

Dekker R, Fleischmann M, Inderfurth K, Van Wassenhove LN (Eds.). 2003. Reverse Logistics: Quantitative Models for Closed-Loop Supply Chains. Springer: Berlin. de Koster MBM. 2002a. The logistics behind the enter click. In: A Klose, LN Van Wassenhove (Eds), Quantitative Approaches to Distribution Logistics and Supply Chain Management. Springer: Berlin;2002. p. 131-148 de Koster MBM. 2002b. Distribution structures for food home shopping. International Journal of Physical Distribution \& Logistics Management 32(5): 362-380 de Koster MBM, Le-Duc T, Roodbergen KJ. 2006. Design and Control of Warehouse Order-Picking: A Literature Review. Working Paper, RSM Erasmus University, Rotterdam, The Netherlands 
Ding Q, Kouvelis P, Milner JM. 2006. Dynamic pricing through discounts for optimizing multiple-class demand fulfillment. Operations Research 54(1): 169-183

Dinlersoz EM, Hernandez-Murillo R. 2005. The diffusion of electronic business in the United States. Federal Reserve Bank of St Louis Review 87(1): 11-34

Du TC, Li EY, Chou D. 2005. Dynamic vehicle routing for online B2C delivery. Omega 33(1): $33-45$

Elmaghraby W, Keskinocak P. 2003. Dynamic pricing in the presence of inventory considerations: Research overview, current practices, and future directions. Management Science 49(10): 1287-1309

Erdem T, Winer R. 2002. Introduction to the Special Issue on Choice Modeling. Marketing Letters 13(3): 157-162

Etzion H, Pinker E, Seidmann A. 2006. Analyzing the simultaneous use of auctions and posted prices for online selling. Manufacturing and Service Operations Management 8(1): 68-91

Fleischmann B, Gnutzmann S, Sandvoß E. 2004. Dynamic vehicle routing based on online traffic information. Transportation Science 38(4): 420-433

Fleischmann B, Meyr H, Wagner M. 2002. Advanced Planning. In: H Stadtler, C Kilger (Eds), Supply Chain Management and Advanced Planning, 2nd ed. Springer: Berlin; 2002. p. 81-106

Fleischmann B, Meyr H. 2003. Customer Orientation in Advanced Planning Systems. In: H Dyckhoff et al. (Eds), Supply Chain Management and Reverse Logistics, Springer: Berlin; 2003. p. 297-321

Fleischmann M, Bloemhof-Ruwaard JM, Beullens P, Dekker R. 2003. Reverse Logistics Network Design. In R Dekker et al. Reverse Logistics: Quantitative Models for Closed-Loop Supply Chains. Springer: Berlin; 2003. p. 65-94

Forrester Research, 2005. Topic Overview: US Online Retail

Francis P, Smilowitz K, Tzur M. 2004. The period vehicle routing problem with service choice. Working paper, Northwestern University, Evanston, IL

Francis P, Smilowitz-Corr K. 2005. Modeling Techniques for Periodic Vehicle Routing Problems. Working paper, Northwestern University, Evanston, IL 
Gallien J. 2006. Dynamic mechanism design for online commerce. Operations Research 54(2): 291-310

Garbarino E, Lee OF. 2003. Dynamic Pricing in Internet Retail: Effects on Consumer Trust. Psychology and Marketing 20(6): 495-513

Gimenez C, Lourenco HR. 2004. e-Supply Chain Management: Review, Implications and Directions for Future Research. Working paper ,Universitat Pompeu Fabra, Barcelona, Spain

Gulati R, Garino J. 2000. Get the right mix of bricks \& clicks. Harvard Business Review 78(3): 107-114

Hsu C-I, Li H-C. 2005. Optimal delivery service strategy for Internet shopping with timedependent consumer demand. Transportation Research Part E (forthcoming)

Jenamani M, Mohapatra PKJ, Ghose S. 2003. A stochastic model of e-customer behavior. Electronic Commerce Research and Applications 2(1): 81-94

Johnson ME, Meller RD. 2002. Performance analysis of split-case sorting systems. Manufacturing \& Service Operations Management 4(4): 258

Johnson ME, Whang S. 2002. E-business and supply chain management: An overview and framework. Production and Operations Management 11(4): 413-423

Kalagnanam J, Parkes DC. 2004. Auctions, bidding and exchange design. In: D SimchiLevi et al. (Eds), Handbook of Quantitative Supply Chain Analysis: Modeling in the EBusiness Era. Kluwer: Boston; 2004. p. 213-246

Kamakura WA, Wedel M, de Rosa F, Mazzon JA. 2003. Cross-selling through database marketing: A mixed data factor analyzer for data augmentation and prediction. International Journal of Research in Marketing 20(1): 45-65

Kamarainen V, Punakivi M. 2002. Developing Cost-effective Operations for the eGrocery Supply Chain. International Journal of Logistics, 5(3): 285-298

Kambil A, Van Heck E. 2002. Making Markets: How Firms Can Design and Profit From Online Auctions and Exchanges. Harvard Business School Press

Keskinocak P, Tayur S. 2001. Quantitative analysis for internet-enabled supply chains. Interfaces 31(2): 70-89

Khouja M. 2001. The evaluation of drop shipping option for e-commerce retailers. Computers \& Industrial Engineering 41(2): 109-126 
Kleijn MJ, Dekker R. 1998. An overview of inventory systems with several demand classes. In: M.G. Speranza, P. Stahly (Eds), New Trends in Distribution Logistics. Springer: Berlin; 1999. p. 253-265

Klose A, Drexl A. 2005. Facility location models for distribution system design. European Journal of Operational Research 162(1): 4-29

Lin II, Mahmassani HS. 2002. Can online grocers deliver? Some logistics considerations, Transportation Record 2002, Washington DC.

Lummus RR, Vokurka RJ. 2002. Making the right e-fulfillment decision. Production and Inventory Management Journal 43(1/2): 50-55

McGill JI, Ryzin GJV. 1999. Revenue Management: Research Overview and Prospects. Transportation Science 33(2): 233-256

Min H, Ko HJ, Ko CS. 2006. A genetic algorithm approach to developing the multiechelon reverse logistics network for product returns. Omega 34(1): 56-69

Mostard J, de Koster R, Teunter R. 2005. The distribution-free newsboy problem with resalable returns. International Journal of Production Economics 97(3): 329-342

Mostard J, Teunter R. 2006. The newsboy problem with resalable returns: A single period model and case study. European Journal of Operational Research 169(1): 81-96

Murphy AJ. 2003. (Re)solving space and time: Fulfilment issues in online grocery retailing. Environment and Planning A 35(7): 1173-1200

Netessine S, Rudi N. 2006. Supply Chain choice on the Internet, Management Science 52(6): $844-864$

Netessine S, Rudi N. 2004. Supply Chain Structures on the Internet and the role of marketing-operations interaction, In: D Simchi-Levi et al. (Eds.), Handbook of Quantitative Supply Chain Analysis: Modeling in the E-Business Era. Kluwer: Boston; 2004. p. 607-642

Netessine S, Savin S, Xiao W. 2005. Dynamic Revenue Management through Crossselling in E-commerce Retailing. Operations Research (Forthcoming)

Nunes PF, Cespedes FV. 2003. The customer has escaped. Harvard Business Review 81(11): 96-105

Punakivi M, Saranen J. 2001a. Identifying the success factors in e-grocery home delivery. International Journal of Retail \& Distribution Management 29(4): 156-163 
Punakivi M, Yrjola H, Holmstrom J. 2001b. Solving the last mile issue: Reception box or delivery box? International Journal of Physical Distribution \& Logistics Management 31(6): 427-439

Punakivi M, Tanskanen k. 2002. Increasing the cost efficiency of e-fulfilment using shared reception boxes. International Journal of Retail \& Distribution Management 30(10): 498-507

Rabinovich E, Bailey JP. 2004. Physical distribution service quality in Internet retailing: Service pricing, transaction attributes, and firm attributes. Journal of Operations Management 21(6): 651-672

Randall T, Netessine S, Rudi N. 2002. Should you take the virtual fulfillment path? Supply Chain Management Review, November/ December: 54-58

Randall T, Netessine S, Rudi N. 2006. An Empirical Examination of the Decision to Invest in Fulfillment Capabilities: A Study of Internet Retailers. Management Science 52(4): $567-580$

Robuste F, Galvan D, Lopez-Pita A. 2003. Modeling e-Logistics for urban B2C in Europe. Transportation Research Board Annual Meeting

Russell ML, Meller RD. 2003. Cost and throughput modeling of manual and automated order fulfillment systems. IIE Transactions 35(7): 589-603

Sarkis J, Meade LM, Talluri S. 2004. E-logistics and the natural environment. Supply Chain Management 9(4): 303-312

Simchi-Levi D, Wu DS, Shen ZJ. (Eds) 2004. Handbook of Quantitative Supply Chain Analysis: Modeling in the E-Business Era. Kluwer: Boston; 2004

Swaminathan JM, Tayur SR. 2003. Models for supply chains in e-business. Management Science 49(10): 1387-1406

Talluri KT, Van Ryzin GJ. 2004. The Theory and Practice of Revenue Management. Springer: New York

Tarn JM, Razi MA, Wen HJ, Jr AAP. 2003. E-fulfillment: the strategy and operational requirements. Logistics Information Management 16(5): 350-362

Toth P, Vigo D, (Eds.). 2001. The Vehicle Routing Problem. Society for Industrial \& Applied Mathematics (SIAM). 
Tsay AA, Nahmias S, Agrawal N. 1998. Modeling Supply Chain Contracts: A Review. In: SR Tayur et al. (Eds), Quantitative Models for Supply Chain Management. Kluwer: Boston; 1999. p. 299-336

Tsay AA, Agrawal N. 2004. Modeling Conflict and Coordination in Multi-Channel

Distribution Systems: A Review. In: D Simchi-Levi et al. (Eds), Modeling in the EBusiness Era. Kluwer: Boston;2004. p.557-606

Van der Laan E, Vlachos D, Kiesmueller D, Kuik R, Dekker R. 2003. Managing Recoverable Inventories, In: R Dekker et al (Eds). Reverse Logistics: Quantitative Models for Closed-Loop Supply Chains, Springer: Berlin; 2003. p.181-220

Van Den Poel D, Buckinx W. 2005. Predicting online-purchasing behaviour. European Journal of Operational Research 166(2): 557-575

Vlachos D, Dekker R. 2003. Return handling options and order quantities for single period products. European Journal of Operational Research 151(1): 38-52

Wallace DW, Giese JL, Johnson JL. 2004. Customer retailer loyalty in the context of multiple channel strategies. Journal of Retailing 80(4): 249-263

Webb KL. 2002. Managing channels of distribution in the age of electronic commerce. Industrial Marketing Management 31(2): 95-102

Weigel D, Cao B. 1999. Applying GIS and OR techniques to solve Sears techniciandispatching and home-delivery problems. Interfaces 29(1): 112-130

Wong RCW, Fu AWC, Wang K. 2005. Data mining for inventory item selection with cross-selling considerations. Data Mining and Knowledge Discovery 11(1): 81-112

Xu PJ. 2005. Order Fulfillment in Online Retailing: What Goes Where. PhD Thesis, Sloan School of Management. Massachusetts Institute of Technology

$\mathrm{Xu}$ PJ, Graves SC, Allgor R. 2006. The benefits of re-evaluating the real-time fulfillment decisions. Manufacturing and Service Operations Management 8(1): 104-107

Yalabik B, Petruzzi NC, Chhajed D. 2005. An integrated product returns model with logistics and marketing coordination. European Journal of Operational Research 161(1): 162-182

Yrjola H. 2001. Physical distribution considerations for electronic grocery shopping. International Journal of Physical Distribution \& Logistics Management 31(9/10): 746-761 


\section{Figures and Tables}

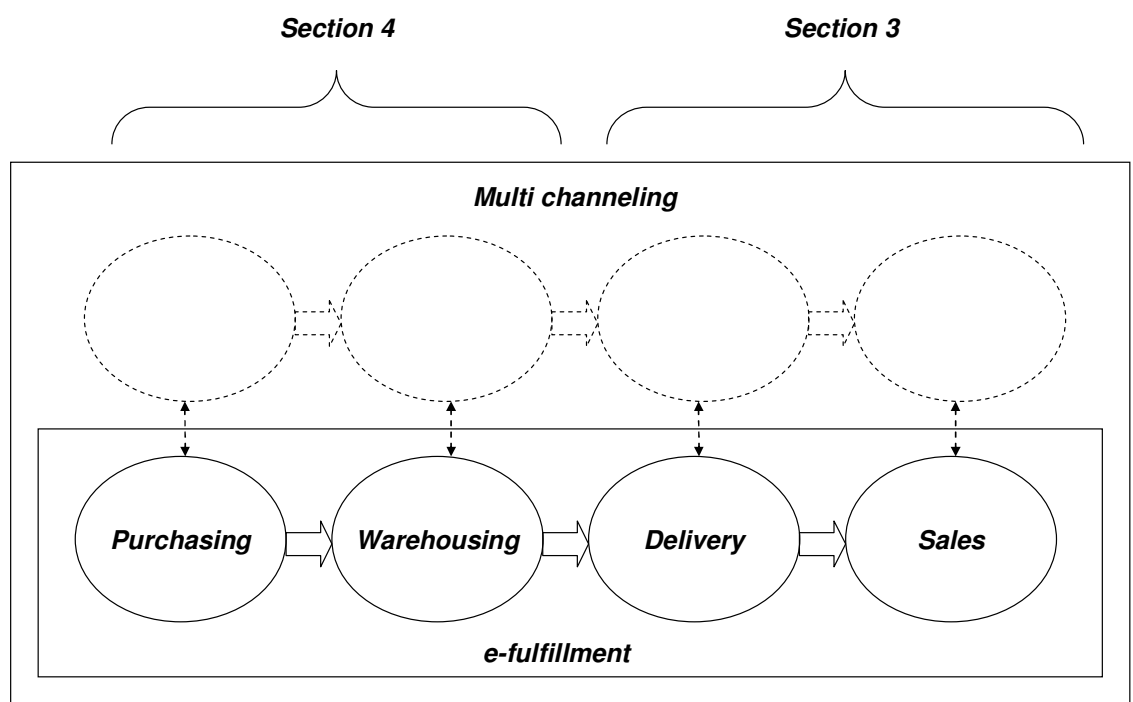

Figure 1: Structuring the Multi-Channel E-fulfillment Distribution Process

\begin{tabular}{|c|c|c|c|}
\hline & & $e$-fulfillment & Multi-channel \\
\hline \multirow{4}{*}{ 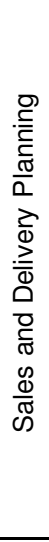 } & $\begin{array}{l}\text { Delivery service } \\
\text { design }\end{array}$ & $\begin{array}{l}\text { last-mile service, } \\
\text { delivery time windows, } \\
\text { return options }\end{array}$ & $\begin{array}{l}\text { store pick-up, } \\
\text { in-store returns }\end{array}$ \\
\hline & $\begin{array}{l}\text { Forecasting and } \\
\text { pricing }\end{array}$ & $\begin{array}{l}\text { delivery fees, } \\
\text { dynamic pricing, } \\
\text { cross selling }\end{array}$ & $\begin{array}{l}\text { price } \\
\text { coordination }\end{array}$ \\
\hline & $\begin{array}{l}\text { Order promising } \\
\text { and revenue } \\
\text { management }\end{array}$ & $\begin{array}{l}\text { delivery yield } \\
\text { management, cost and } \\
\text { revenue based } \\
\text { segmentation }\end{array}$ & $\begin{array}{l}\text { cross-channel } \\
\text { yield } \\
\text { management }\end{array}$ \\
\hline & $\begin{array}{l}\text { Transportation } \\
\text { planning }\end{array}$ & $\begin{array}{l}\text { routing for home } \\
\text { delivery, dynamic } \\
\text { routing }\end{array}$ & joint delivery \\
\hline \multirow{3}{*}{ 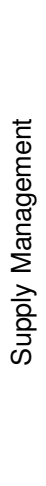 } & $\begin{array}{l}\text { Distribution } \\
\text { network design }\end{array}$ & $\begin{array}{l}\text { inventory location, drop- } \\
\text { shipping }\end{array}$ & $\begin{array}{l}\text { inventory } \\
\text { aggregation, } \\
\text { shared facilities }\end{array}$ \\
\hline & $\begin{array}{l}\text { Warehouse } \\
\text { design }\end{array}$ & $\begin{array}{l}\text { degree of automation, } \\
\text { warehouse layout, } \\
\text { return handling }\end{array}$ & $\begin{array}{l}\text { different } \\
\text { transaction sizes }\end{array}$ \\
\hline & $\begin{array}{l}\text { Inventory and } \\
\text { capacity } \\
\text { management }\end{array}$ & $\begin{array}{l}\text { safety stocks, } \\
\text { integration with demand } \\
\text { management, inventory } \\
\text { rationing, integration of } \\
\text { returns, staffing levels }\end{array}$ & $\begin{array}{l}\text { aggregate stock } \\
\text { levels, service } \\
\text { differentiation }\end{array}$ \\
\hline
\end{tabular}

Table 1: Issues in E-Fulfillment and Multi-Channel Distribution 


\begin{tabular}{|c|c|c|c|c|c|c|c|c|c|c|c|c|}
\hline & & \multicolumn{8}{|c|}{ quantitative models } & & & \\
\hline \multirow{4}{*}{ 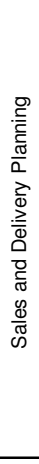 } & $\begin{array}{l}\text { Delivery service } \\
\text { design }\end{array}$ & Yrjola (2001) & $\begin{array}{l}\text { Punakivi et } \\
\text { al. (2001a,b, } \\
\text { 2002) }\end{array}$ & $\begin{array}{l}\text { Lin and } \\
\text { Mahma } \\
\text { ssani } \\
(2001)\end{array}$ & $\begin{array}{l}\text { Robuste et } \\
\text { al. (2003) }\end{array}$ & $\begin{array}{l}\mathrm{Hsu} \text { and } \mathrm{Li} \\
(2005)\end{array}$ & $\begin{array}{l}\text { Yalabik et } \\
\text { al. (2005) }\end{array}$ & & & & & \\
\hline & $\begin{array}{l}\text { Pricing and } \\
\text { forecasting }\end{array}$ & $\begin{array}{l}\text { Kalagnanam } \\
\text { and Parkes } \\
(2004)^{*}\end{array}$ & $\begin{array}{l}\text { Chan et al. } \\
(2004) *\end{array}$ & $\begin{array}{l}\text { Elmagh } \\
\text { raby } \\
\text { and } \\
\text { Keskino }\end{array}$ & $\begin{array}{l}\text { Asdemir et } \\
\text { al. (2002) }\end{array}$ & $\begin{array}{l}\text { Campbell } \\
\text { and } \\
\text { Savelberg } \\
(2006)\end{array}$ & $\begin{array}{l}\text { Kamakur } \\
\text { a et al. } \\
(2003)\end{array}$ & $\begin{array}{l}\text { Wong et } \\
\text { al.(20005) }\end{array}$ & $\begin{array}{l}\text { Netessine } \\
\text { et al. (2005) }\end{array}$ & $\begin{array}{l}\text { Akcura } \\
\text { and } \\
\text { Srinivasan } \\
(2005)\end{array}$ & $\begin{array}{l}\text { Cattani } \\
\text { et al.* } \\
(2004)\end{array}$ & $\begin{array}{l}\text { Cattani et } \\
\text { al. (2006) }\end{array}$ \\
\hline & $\begin{array}{l}\text { Order promising } \\
\text { and revenue } \\
\text { management }\end{array}$ & $\begin{array}{l}\text { Talluri and } \\
\text { van Ryzin } \\
(2004)^{*}\end{array}$ & $\begin{array}{l}\text { Campbell \& } \\
\text { Savelbergh } \\
(2005)\end{array}$ & & & & & & & & & \\
\hline & $\begin{array}{l}\text { Transportation } \\
\text { planning }\end{array}$ & $\begin{array}{l}\text { Toth and } \\
\text { Vigo }(2001)^{*}\end{array}$ & $\begin{array}{l}\text { Braysy and } \\
\text { Gendreau } \\
(2005)^{*}\end{array}$ & $\begin{array}{l}\text { Fleisch } \\
\text { mann et } \\
\text { al. } \\
(2004) \\
\end{array}$ & $\begin{array}{l}\text { Francis et } \\
\text { al. } \\
(2004,2005)\end{array}$ & $\begin{array}{l}\text { Weigel } \\
\text { and Cao } \\
(1999)\end{array}$ & $\begin{array}{l}\text { Du et al. } \\
(2005)\end{array}$ & $\begin{array}{l}\text { Xu et al. } \\
(2006)\end{array}$ & & & & \\
\hline $\begin{array}{l}\overrightarrow{\mathrm{c}} \\
\underline{\Phi}\end{array}$ & $\begin{array}{l}\text { Distribution } \\
\text { network design }\end{array}$ & $\begin{array}{l}\text { Klose and } \\
\text { Drexl. } \\
(2005)^{*}\end{array}$ & $\begin{array}{l}\text { Netessine } \\
\text { and Rudi } \\
(2006 \\
2004))\end{array}$ & $\begin{array}{l}\text { Min et } \\
\text { al. } \\
(2006)\end{array}$ & $\begin{array}{l}\text { Alptekinoglu } \\
\text { and Tang } \\
(2005)\end{array}$ & $\begin{array}{l}\text { Chiang } \\
\text { and } \\
\text { Monahan } \\
(2005)\end{array}$ & & & & & & \\
\hline 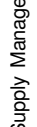 & $\begin{array}{l}\text { Warehouse } \\
\text { design }\end{array}$ & $\begin{array}{l}\text { Koster et al. } \\
(2006)^{*}\end{array}$ & $\begin{array}{l}\text { Johnson and } \\
\text { Meller } \\
(2002)\end{array}$ & $\begin{array}{l}\text { Russel } \\
\text { and } \\
\text { Meller } \\
(2002)\end{array}$ & $\mathrm{Xu}(2005)$ & $\begin{array}{l}\text { Brito and } \\
\text { de Koster } \\
(2003) *\end{array}$ & & & & & & \\
\hline & $\begin{array}{l}\text { Inventory and } \\
\text { capacity } \\
\text { management }\end{array}$ & $\begin{array}{l}\text { Kleijn and } \\
\text { Dekker } \\
(1998)^{*}\end{array}$ & $\begin{array}{l}\text { Cattani and } \\
\text { Souza } \\
(2002)\end{array}$ & $\begin{array}{l}\text { Ayanso } \\
\text { et al. } \\
(2006)\end{array}$ & $\begin{array}{l}\text { Ding et al. } \\
(2006)\end{array}$ & $\begin{array}{l}\text { Bailey and } \\
\text { Rabinovich } \\
(2005)\end{array}$ & $\begin{array}{l}\text { Khouja } \\
(2001)\end{array}$ & $\begin{array}{l}\text { van der } \\
\text { Laan et al. } \\
(2004)^{*}\end{array}$ & $\begin{array}{l}\text { Vlachos } \\
\text { and Dekker } \\
(2003)\end{array}$ & $\begin{array}{l}\text { Mostard et } \\
\text { al. (2005, } \\
2006)\end{array}$ & & \\
\hline & & * review paper & / textbook & & & & & & & & & \\
\hline
\end{tabular}

Table 2: Quantitative Models for E-Fulfillment and Multi-Channel Distribution 


\section{Publications in the Report Series Research ${ }^{*}$ in Management}

\section{ERIM Research Program: "Business Processes, Logistics and Information Systems"}

2006

Smart Business Networks Design and Business Genetics

L-F Pau

ERS-2006-002-LIS

http://hdl.handle.net/1765/7319

Designing and Evaluating Sustainable Logistics Networks

J. Quariguasi Frota Neto, J.M. Bloemhof-Ruwaard, J.A.E.E. van Nunen and H.W.G.M. van Heck ERS-2006-003-LIS

http://hdl.handle.net/1765/7320

Design and Control of Warehouse Order Picking: a literature review

René de Koster, Tho Le-Duc and Kees Jan Roodbergen

ERS-2006-005-LIS

http://hdl.handle.net/1765/7322

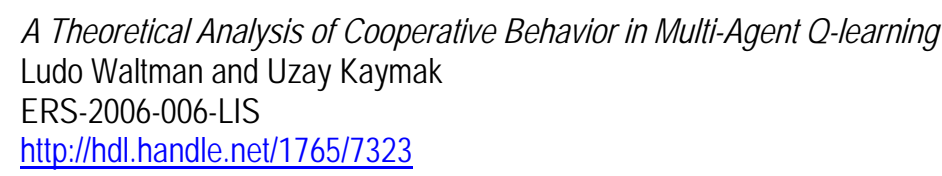

Supply-Chain Culture Clashes in Europe. Pitfalls in Japanese Service Operations M.B.M. de Koster and M. Shinohara

ERS-2006-007-LIS

http://hdl.handle.net/1765/7330

From Discrete-Time Models to Continuous-Time, Asynchronous Models of Financial Markets Katalin Boer, Uzay Kaymak and Jaap Spiering

ERS-2006-009-LIS

http://hdl.handle.net/1765/7546

Mobile Payments in the Netherlands: Adoption Bottlenecks and Opportunities, or... Throw Out Your Wallets Farhat Shaista Waris, Fatma Maqsoom Mubarik and L-F Pau

ERS-2006-012-LIS

http://hdl.handle.net/1765/7593

Hybrid Meta-Heuristics for Robust Scheduling M. Surico, U. Kaymak, D. Naso and R. Dekker ERS-2006-018-LIS

http://hdl.handle.net/1765/7644

VOS: A New Method for Visualizing Similarities between Objects

Nees Jan van Eck and Ludo Waltman

ERS-2006-020-LIS

http://hdl.handle.net/1765/7654

On Noncooperative Games, Minimax Theorems and Equilibrium Problems

J.B.G. Frenk and G. Kassay

ERS-2006-022-LIS

http://hdl.handle.net/1765/7809 
An Integrated Approach to Single-Leg Airline Revenue Management: The Role of Robust Optimization S. Ilker Birbil, J.B.G. Frenk, Joaquim A.S. Gromicho and Shuzhong Zhang

ERS-2006-023-LIS

http://hdll.handle.net/1765/7808

Optimal Storage Rack Design for a 3D Compact AS/RS with Full Turnover-Based Storage

Yu Yugang and M.B.M. de Koster

ERS-2006-026-LIS

http://hdll.handle.net/1765/7831

Optimal Storage Rack Design for a 3-dimensional Compact AS/RS

Tho Le-Duc, M.B.M. de Koster and Yu Yugang

ERS-2006-027-LIS

http://hdl.handle.net/1765/7839

E-Fulfillment and Multi-Channel Distribution - A Review

Niels Agatz, Moritz Fleischmann and Jo van Nunen

ERS-2006-042-LIS

Leveraging Offshore IT Outsoutcing by SMEs through Online Marketplaces

Uladzimir Radkevitch, Eric van Heck and Otto Koppius

ERS-2006-045-LIS

* A complete overview of the ERIM Report Series Research in Management: https://ep.eur.n//handle/1765/1

ERIM Research Programs:

LIS Business Processes, Logistics and Information Systems

ORG Organizing for Performance

MKT Marketing

F\&A Finance and Accounting

STR Strategy and Entrepreneurship 